\title{
Communicating Development Successes, Results and Impact
}

Lester Dally

Acting Special Representatives, Japan \& Korea, World Bank

Minister Song, Vice Minister, Excellencies, Distinguished Panelists and Guests:

I want to sincerely thank our Korean hosts MOFAT very much and also appreciate the invitation from KOICA, the organizers of this conference, to the World Bank to participate.

Let me firstly start by making a few brief observations about Korea's overall strategy for development assistance.

Korea's valuable and unique assets to development are in fact its own development experiences over 40 years. Lessons and expertise from Korea are valuable to other developing countries and demonstrate how to achieve growth and reduce poverty. The
Korean story is unique and capable of being repeated in other countries and regions.

Korea needs to continue to develop its development assistance strategy, policies and operations based on its own experience and share Korean know how with the global development community.

As a new global donor, Korea needs to continue to work closely with organizations like OECD DAC and the global development community, both multilateral and bilateral donors, to learn and share experiences and coordinate strategies and implementation.

ODA authorities and opinion leaders in the Korean development community need to build 
a clear case for broad public support of its development assistance policies. Endeavor to enhance national consensus and raise public awareness through outreach with parliamentarians, media and other important constituencies, including the private sector.

In implementation, communications is critical. There is a need to develop a strong program to communicate the success and impact of Korea's ODA program, as clear demonstration of results will not only deepen public support but also engage a broader set of Korean partners to work in the design and implementation of the development program. It is also fundamental that recipient countries appreciate the power and importance of communication to our shared goal of eradicating poverty, improving governance and changing the lives of people around the world. Korea has demonstrated this in its own development process where communication and ICT was a fundamental building block in the process of change.

Information and communication can change whole societies, which depend on accurate information, information that can educate and make good decisions more likely.
When people do not have access to information, corrupt acts are concealed, people are excluded from opportunities, and markets are distorted.

With a free flow of information, or at least a freer flow of information, governments are more likely to make decisions on financial allocations that are in the interests of their citizens.

Governments receiving development assistance cannot be held accountable if there are no mechanisms for disclosing their actions in the court of public opinion,

In our efforts to communicate what development is all about, building free, open, transparent and equitable societies where governments have the capacity to inform and engage citizens in policy dialogue, where citizens have the capacity to hold their governments to account, where journalists have access to the information they need and the capacity to report in the public interest, where both civil society and marginalized groups have the right to organize and assemble and voice their needs and aspirations and make or at least shape the 
decisions that affects their lives.

The story of how Uganda used information and communication to radically reduce corruption in its education grants program is an excellent example. But it is such a powerful example that it bears repeating. It is remarkable for both its simplicity and its impact. In 1995, for every dollar the central government of Uganda was spending on education, only 20 cents was actually reaching the schools. Local governments captured the rest and it disappeared. Then the central government started to publicize data on the monthly grant transfers in newspapers and on the radio. In other words, they used the tools of communication to get the information to schools and parents to keep the grant program accountable. By 2001, 80 cents out of every dollar spent actually reached the schools.

This is an example of the essential role of targeted communication in the fight for transparency and against corruption. It is also an example of the contribution communication can make to technical prescriptions in development projects.
In this case, simply improving the financial management system around the grants scheme was not enough.

It was communication and information that made the difference. Simply providing information empowered poor people to take charge of the quality of education provided for their children.

Finally, let me now turn briefly to Vietnam as an example of how we can communicate the success and results of our development joint development activities with other major donors. Please refer to the handout on Vietnam at Work.

\section{IDA AT WORK}

\section{Vietnam: Laying the Foundation for Steady Growth}

Vietnam is one of the best-performing developing economies in the world. It is going through a far-reaching transformation from an inward-looking planned economy to one that is globalized and market-based. It has the potential to be one of the great success 
stories in development.

Real income has grown 7.3 percent per year over the last 10 years. When the World Bank reengaged

with Vietnam in 1993, income per capita was US\$170. Today it is US\$620, and by 2010 it could reach US $\$ 1,000$. The poverty rate has fallen from 58 percent in 1993 to less than 20 percent in 2004. Vietnam can reach most of the Millennium Development Goals.

Vietnam is a major recipient of IDA resources, although it is not an aid-dependent country. The World Bank is the coordinator of foreign aid to Vietnam because of the large volume of resources it mobilizes and especially because of the Bank's recognized technical expertise. This has led to a very effective dialogue on the policy reforms that underpin Vietnam's transition to a market-based economy.

\section{COUNTRY ACHIEVEMENTS}

\section{Vietnam's development achievements have been remarkable.}

By the mid-1980s, this war-ravaged country faced famine and a failing command economy. The government launched a renovation process (Doi Moi) in 1986, even as it saw the collapse of the Soviet Union.its main market and a vital source of foreign assistance.and had to deal with a domestic fiscal crisis and hyperinflation. Doi Moi experimented with market mechanisms while trying to preserve social inclusion.

\begin{tabular}{|c|c|c|}
\hline Country Indicators & 1993 & 2005 \\
\hline GNI per capita (Atlas method, US\$) & 170 & 620 \\
\hline Inflation (CPI, annual rate, \%) & 8.4 & 8.4 \\
\hline External debt (\% of GNI) & 191 & 33 \\
\hline \multicolumn{3}{|l|}{ Poverty incidence (\% of population with } \\
\hline consumption below basic needs level) & 58 & $20(2004)$ \\
\hline Net primary school enrollment rate (\%) & 77 (1990) & 94(2004) \\
\hline Under-five child mortality rate (per 1,000 ) & $53(1990)$ & $23(2004)$ \\
\hline Maternal mortality rate (per 100,000 live births) & 200 & 80 \\
\hline Population (millions) & 70.3 & 83 \\
\hline Population growth rate (\% per year) & 2 & 1 \\
\hline
\end{tabular}

Source: Vietnam, General Statistics Office; World Bank, Development Data Group. 
An egalitarian redistribution of farmland, coupled with freer trade in agricultural products and better agricultural support services at the local level, led to a boom in farm exports and a dramatic reduction in rural poverty.

Foreign investment grew as the domestic entrepreneurial spirit was unleashed. Urban residents moved into paid employment, helping to reduce the number of rural poor even more.

Vietnam's economy expanded rapidly. It avoided the economic collapse that other transition economies went through in the early 1990s as well as the economic crisis that several East Asian countries suffered in the late 1990s. The economic growth rate has exceeded 8 percent in the last two years and the country is now aiming for middle-income country status by 2010 .

\section{An institutional overhaul accompanied rapid economic growth.}

With its development strategy clearly producing results, the government decided to deepen economic reforms.
A new State budget law has led to major steps forward in public financial management with improved transparency, increased disclosure, and a forum for public consultation. Legal and regulatory policy frameworks for energy, water, and forestry as well as for investment and enterprises also are in place.

These institutional improvements establish a strong base for sustained economic performance. In addition, Vietnam recorded important progress in the sale of state assets and adoption of an ambitious roadmap for the reform of the financial sector. Accession to the World Trade Organization (WTO) in January 2007 will see its farms and firms open to competition and its legal system modernized.

\section{The private sector has emerged as the driver of growth.}

As in China, the transition to a competitive market economy is well under way, driving Vietnam's growth and increasing its resilience.

Private enterprises, whose activities were 
negligible in 1993, now account for over half of the investments made each year. Faced with increased domestic and international competition and other measures to increase effi ciency, state-owned firms have done reasonably well in recent years. Threequarters of them return a profit, with rates of return on equity of 7.8 percent per year.

Massive privatization cut the number of state firms by half, to 3,000 , over the past five years, although only in select areas. This has created increased space for the expansion of private firms.

As the private sector expands rapidly, both domestic and foreign-invested firms have connected solidly with global markets. Private firms now contribute 65 percent of manufactured products and over 70 percent of non-oil exports. Vietnam is more and more an integral part of international production and distribution chains.

\section{IDA CONTRIBUTIONS}

The International Development Association (IDA), the World Bank's fund for low-income countries, has helped Vietnam fi ght povertthrough finance for agriculture, infrastructure, health programs, and schools, among other things. The country has received more than US\$6 billion in interestfree credits and grants from IDA, the second largest provider of aid to Vietnam after Japan.

Still, Vietnam is not aid-dependent. Foreign assistance represents only about 15 percent of total public spending. This forces donors to lift their games and focus their efforts on policy dialogue, research, and investments in key development areas.

\section{Since 1993, the Bank's partnership with Vietnam has contributed to achieving notable results.}

\section{Supporting policy reforms.}

Policy dialogue arguably has had the biggest impact of all donor contributions as it underpins the reforms which are transforming the entire economic system.

Some work has directly affected the government's programs and policies. For 
example, World Bank research for the national targeted program for poverty reduction resulted in communities participating more in the planning and implementation stages of community-based infrastructure such as clinics and local roads.

Five poverty reduction support credits (PRSCs) have now been completed with the active participation of 19 donors $^{1)}$ and $\mathrm{co}^{-}$ financing by 11 of them. These credits have supported reforms in six main areas: trade integration; financial and state owned enterprise reform; infrastructure; social sector issues (health, education, social protection); natural resource management;

\section{Some of the benefits of reforms supported by IDA credits include:}

- Steps to transform the State Bank of Vietnam into a modern central bank

- School quality standards that have improved the quality of teaching

- Land user certificates that list the names of both husbands and wives, thereby allowing women to use the certificates as collateral for bank credits

- A state budget plan disclosed to the public for the first time in 2005

- An enterprise law (2000) that doubled the total number of registered enterprises and leveled the playing field for domestic, foreign, state-owned and private enterprises and governance. Specific actions in each area were sequenced carefully to match implementation capacity and exploit synergies across sectors.

\section{Building local capacity}

According to the World Bank's latest client survey, IDA's greatest contributions are knowledge and technical expertise.

Its approach has been to build government capacity to undertake its own research for its own purposes.

For example, while the Bank conducted Vietnam's first poverty assessment, the second was undertaken jointly with the government. Now the government is doing its own, with the Bank's advice.

In education, the Bank has helped build capacity in setting minimum standards for primary education (for example in teacher qualification), the quality of textbooks, and primary teacher competency profi les. These standards link to national budget allocations. Through a series of IDA education projects,

1) The 19 donors are: Asian Development Bank, Australia, Belgium, Canada, Denmark, the European Commission (EC), Finland, France, Germany, Ireland, Japan, Luxembourg, the Netherlands, Norway, Spain, Sweden, Switzerland, the United Kingdom, and UNDP. 
the government is scaling up these innovations geographically and through higher levels of the education system.

Several investment credits aim to revamp business processes in ways that improve efficiency in the use of public resources and increase transparency. They target the agencies more vulnerable to corruption, including customs, and tax and land administration.

\section{Setting Up Systems for Lasting Change}

- "Our work with the government of Vietnam has focused on systemic issues of education," says Klaus Rohland, the World Bank' s Country Director for Vietnam.

- "At first we built schools.and we still build schools because Vietnam needs more schools than it has. But we have also focused on issues such as teacher training. We' ve worked with the ministry of education and seen a change of attitude. Rather than being a simple provider of education, the ministry now drafts policy for education and focuses on quality.an area where we can bring our international experience to the table.

- It' $s$ the same in the health sector or when it comes to roads. We' re not merely building roads but setting up systems for road maintenance. These systemic issues are at the forefront of our work in Vietnam now.and for the next 5 or so years as Vietnam completes its transition to a market economy."

\section{Coordinating and triggering other donors' support.}

Vietnam receives close to US\$3 billion a year from more than 30 bilateral and multilateral donor institutions. The World Bank serves as the coordinator and, often, a catalyst for foreign aid to Vietnam not only because of the funds it mobilizes but also because of its recognized technical expertise.

It co-chairs consultative group meetings with the government, leads the poverty reduction support process, and increasingly fosters multi-donor credits and initiatives. This includes the public financial management modernization, education for all, and forestry partnerships.all good examples of multidonor support for government programs. ${ }^{2}$ Vietnam is now seen as a model for aid harmonization.

\section{Providing good-practice models.}

Investment credits and technical assistance. for example on water basin management or

2) The donors involved in public financial management are: Canada, Denmark, the EC, Sweden, Switzerland, Netherlands, Norway, and the UK. Education initiatives involve Belgium, Canada, the EC, New Zealand, and the United Kingdom. Forestry is supported by the Netherlands, Finland, the $\mathrm{EC}$, and GEF. 
infrastructure.have provided demonstration effects, influencing government approaches at the technical and policy levels.

IDA expertise on phasing, sequencing, and working across sectors has strengthened the effectiveness of development aid. For example, in the context of the broader infrastructure development undertaken at the national and provincial level, the government has embraced projects that are driven by local communities rather than managed from Hanoi. Energy projects have opened the door to private participation in infrastructure. A credit to support schools in poor areas has led to nationwide standards on school quality and the regular auditing of schools against those standards.

\section{IDA's impact is felt across sectors.}

Transport: By 2004, 83 percent of the Vietnamese population was living within 2 kilometers of an all-weather road, up from 30 percent in 1993. IDA financed the repair of 1,000 kilometers of Highway One.the country's main transportation artery.with another 900 kilometers of repairs under way. IDA has also helped build more than 7,000 kilometers of provincial and rural roads. As a result, 6 to 8 million people have better access to the transport system, speeding up their ability to reach markets, schools, health centers, or hospitals.

Electricity: As a result of the government's rural electrification program, more than 90 percent of rural households now have electricity compared to just over 50 percent 10 years ago. IDA helped design this overall effort and implement it through several projects. One brought electricity to around 2.7 million people in poor rural areas. Already, this has transformed hundreds of rural communities, enabling small businesses to grow and improving the services of schools and health facilities. A second project will improve access to electricity for millions more.

Education: School attendance has dramatically improved, with net primary enrollment increasing from 86 percent in 1993 to 94 percent in 2004. For the poorest fifth of the population, the increase was from 71 to 91 percent. For the vulnerable ethnic 
minority communities, the gain was from 62 to 88 percent. IDA has put more than 80 million grammar and mathematics textbooks into primary schools across Vietnam, built around 12,000 classrooms, and strengthened teacher training.

Health: IDA has brought about improvements in the quality of health services and national programs for malaria, tuberculosis, and acute respiratory infections. IDA's contributions have financed essential drugs for healthcare centers; constructed and upgraded 15 health and family planning centers, 137 obstetric and operating rooms in district hospitals, and more than 2,500 communal health centers; and trained 22,000 health workers in more than 2,800 communities in the 18 poorest provinces. Infant mortality has fallen from 30 per 1,000 live births in 1997 to 18 in 2002. Under-five child mortality has also dropped.

\section{Agriculture and rural growth: A quarter of} a million households have benefited from IDAfi nanced rural finance projects. They have provided nearly 850,000 loans throughout rural Vietnam for expanding farm production and off-farm employment,
A Virtuous Circle

- "Infrastructure services are proving to be affordable and sustainable. The expansion of services was coordinated with budgetary and fi nancial reforms. Rapid growth and economic diversification, in turn, have increased demand for services while allowing service providers to increase the scale of their operations and lower their costs.

contributing to the creation of more than 200,000 rural jobs. IDA's rural sector lending has also contributed to increased cropping intensity and better flood control through improvements in 44 irrigation and drainage schemes in the Mekong Delta region. IDA's efforts in agricultural diversification have helped establish more than 23,000 hectares of rubber smallholdings.

Urban poor: Through IDA assistance, 2.7 million people in three cities, including Hanoi, have benefited from improved or new water supply services. Projects are under way to improve livelihoods of close to three million urban citizens, many of them poor, by providing access to basic infrastructure services, reducing flooding, and collecting and treating wastewater and solid waste. 


\section{CHALLENGES AHEAD}

The next five years will be critical. By the end of this period, the transition to a market economy will be complete and Vietnam will have laid the institutional foundations of a middle-income country.

Whether these will be strong enough to keep growth sustainable and inclusive will depend on policy decisions made during the next five years. This makes it all the more important for donors to sustain a high level of assistance in support of the country's move to middle-income country status.

\section{As Vietnam's economy becomes more sophisticated, new challenges emerge.}

For example, mobilizing resources for investment requires a vibrant capital market. Stronger frameworks for private participation in infrastructure development and more economic space for private firms are also vital. In health, the challenge will be to combine efficiency with adequate access for the poor. Rapid growth is putting a heavier burden on natural resources and environmental sustainability, so there is an urgent need for integrated land-use planning, river-basin management, and effective pollution control instruments.

A more sophisticated economy requires better feedback mechanisms from the people on the quality of public policies, and that means increased transparency and accountability.

For example:

- Reforms of banking and state-owned enterprises will need to focus on competition and set best practice standards of transparency and good governance. This has become more pressing with Vietnam's accession to the WTO.

- Massive urbanization and land conversion and a still weak legal system will amplify opportunities for corruption.

Continued economic growth will depend very much on the government's ability to tackle these issues over the next fi ve-year periods.

\section{These priorities call for stronger IDA support.}

Supporting good policy choices, especially for governance, and strengthening government 


\section{Thinking Ahead}

- 'Today, more than 90 percent of Vietnam's rural households have electricity. Vietnam's fi rst rural energy project, partially financed by IDA, has spread the benefits of electricity to around 2.7 million people in the poorest areas of Vietnam. People are able to earn more money, study longer, and receive improved healthcare.

- A little girl described how she used to spend four hours a day grinding rice for her family and maize for the pigs. With an electricity-powered machine, she says she can "do the work in one hour."

- IDA is helping the Government plan the next phase of its rural electrification program. Three IDA-supported projects, stretching to 2010, will help improve distribution and spread coverage to the most remote and isolated households.

systems are important priorities in the short to medium term. But the cost of implementing these will be high.

Recapitalizing state-owned commercial banks and divesting and reforming large state-owned enterprises will lead to redundancies and require an effective social safety net.

Funding infrastructure development is another costly priority. Investment in transport, energy, water, and sanitation needs to be expanded rapidly if the country is to avoid development bottlenecks and attain the key Millennium Development Goals.
Tax revenue alone will not be enough and massive borrowing in international markets could raise the public debt burden beyond prudent levels. Aid on concessionary terms has an important role to play until Vietnam's infrastructure catches up with that of its neighbors and competitors.

\section{Keeping growth inclusive.}

Resources are still needed to keep growth inclusive. For most of the period after Doi Moi, reducing poverty was mainly an economic issue. Now, poverty efforts are increasingly focused on ethnic minority groups.

Sustained transfers of funds are needed to ensure that the living standards of these groups do not fall further behind those of the majority. IDA resources could be used, for example, to enhance the government's targeted poverty reduction program and national urban (slum) upgrading plan. Vietnam is also trying to build universal programs for health and social insurance. Protecting the gains achieved in health and laying out the foundations of a strong social 
insurance system will need considerable financial resources over the next 5 to 10 years.

Public investment needs and the cost of major reforms are likely to range from US $\$ 16$ to US\$18 billion each year until 2010.

Using current estimates of cost sharing with the government and realistic projections of private participation in infrastructure, this implies a need for IDA resources of about US\$900 million to US\$1.1 billion per year.

\section{Learning from experience.}

According to World Bank assessments, Vietnam is one of three borrowing countries achieving the highest quality outcomes for the period 2000 to 2004.

The impact of IDA programs on institutional development is especially noteworthy. Cao Viet Sinh, Vietnam's Vice Minister for Planning and Investment, gives the World Bank credit for "solving Vietnam's long-term problems through its Country Assistance Strategies," an evaluation reflected in client surveys in 2003 and 2005. In particular, complex projects that have addressed crosssectoral problems were considered more successful than in many other countries.

Despite the good ratings, all stakeholders recognize that the pace of project preparation and implementation is still slow.

Harmonizing donor procedures and aligning them with Government processes will be vital to speeding up the delivery and completion of projects.

February 2007. http://www.worldbank.org/ida 